\title{
Feeding Ecology of Short-Toed Snake-Eagle (Circaetus gallicus [Gmelin, 1788]) in the Montados of Iberian Peninsula
}

\author{
Nuno Onofre* and Luis Sampaio**
}

\begin{abstract}
The diet of Short-toed Snake-eagle (Circaetus gallicus) during the breeding season in an area dominated by cork and holm oak parkland forests (Montados) was analyzed in this study. As expected, results showed that snakes are the dominant prey in the diet of this eagle, comprising up to $92.5 \%$ of the identified items, if potential secondary prey species were excluded. The Montpellier Snake (Malpolon monspessulanus) was the most consumed one $(42.2 \%)$, followed by the Ladder Snake (Zamenis scalaris) (28.0\%), and the water snakes (Natrix spp.) (14.2\%). According to the same criteria, lizards (mainly Psammodromus algirus) and mammals represent between 4.8 and 2.2\%, respectively. Other animals such as pond turtle and amphibians are irregular prey $(<1 \%)$, and no bird remains were found at all. Short-toed Snake-eagle is usually referred as a stenophagic predator where snakes are by far its most important prey type, and where within this taxonomic group it behaves as a generalist predator. In this study this premise was then tested comparing the relative abundance of the snake species with their proportion in the diet composition of the eagle in order to know whether or not prey selection exists with regard to the species of snakes in this region. Results point to a quite plausible "preference" for the Ladder Snake and an "avoidance" for the smooth snakes group (Macroprotodon brevis/Coronella girondica), and possibly for the Horseshoe Whip (Hemorrhois hippocrepis). The avoidance to the Horseshoe Whip must be indirect and habitat related, while in relation to the two smooth snakes it may be due in large extend to its small size, in particular.
\end{abstract}

Key words: Bird of prey; food, ophiophagy; Quercus suber and Quercus roundifolia

\footnotetext{
* Instituto Nacional de Investigação Agrária e Veterinária, I.P. Av. da República, Quinta do Marquês, 2780-159 Oeiras.

E-mail: nuno.onofre@iniav.pt

**Deceased. Universidade da Madeira, Departamento de Biologia, Portugal.
} 
Ecologia Alimentar da Águia-Cobreira (Circaetus gallicus [Gmelin, 1788]) em Montados da Península Ibérica

Sumário. A dieta de uma população de Águia-cobreira (Circaetus gallicus) durante o período de reprodução numa área dominada por Montados de sobro e azinho foi analisada neste trabalho. Como esperado, os resultados mostraram que as serpentes são o tipo de presa predominante na dieta da Águia-cobreira, compreendendo até $92,5 \%$ dos itens identificados, caso as potenciais presas secundárias sejam descontadas. A Cobrarateira (Malpolon monspessulanus) foi a espécie de serpente mais consumida $(42,2 \%)$, seguida da Cobra-de-escada (Zamenis scalaris) $(28,0 \%)$ e das cobras de água (Natrix spp.) $(14,2 \%)$. De acordo com os mesmos critérios, os lacertídeos (principalmente Psammodromus algirus) e os mamíferos representam entre 4,8 e 2,2\%, respectivamente. Outros animais, como cágados e anfíbios são presas esporádicas $(<1 \%)$ e não se encontrou nenhum resto de ave. A Águia-cobreira é geralmente referida como um predador estenófago onde as cobras são de longe o seu tipo de presa mais importante e onde, dentro deste grupo taxonómico, ela se comporta como um predador generalista. Neste estudo, testou-se então esta premissa comparando a abundância relativa das espécies de cobras com a sua proporção na composição da dieta da águia, a fim de saber se existe ou não selecção de presa no que respeita às espécies de serpentes nesta região. Os resultados apontam para uma "preferência" bastante plausível pela Cobra-de-escada e uma "evitação" pelo grupo das cobras lisas (Macroprotodon brevis/Coronella girondica) e, possivelmente, também pela Cobra-de-ferradura (Hemorrhois hippocrepis). A "evitação" da Cobra-de-ferradura deve ser indirecta e relacionada com o habitat, enquanto em relação às duas cobras lisas poderá ser devido, em particular, ao seu pequeno tamanho.

Palavras-chave: Aves de rapina; alimentação; ofiofagia; Quercus suber e Quercus rotundifolia

Écologie Alimentaire du Circaète Jean-le-Blanc (Circaetus gallicus [Gmelin, 1788]) dans les Montados de la Péninsule Ibérique

Résumé. L'alimentation pendant la saison de reproduction d'une population de Circaète Jean-le-Blanc (Circaetus gallicus) dans une région dominée par les forêts de liège et de chênes verts (Montados) a été analysé dans ce travail. Comme prévu, les résultats ont montré que les serpents sont la proie prédominante du régime alimentaire de cet aigle, comprenant jusqu'à $92,5 \%$ dès item identifiés, si l'on ne compte pas des proies secondaires potentielles. La Couleuvre de Montpellier (Malpolon monspessulanus) est la plus consommé $(42,2 \%)$, suivie par la Couleuvre à échelons (Zamenis scalaris) $(28,0 \%)$ et les serpents d'eau (Natrix spp.) (14,2\%). Selon les mêmes critères, les lézards (principalement Psammodromus algirus) et les mammifères représentent entre 4,8 et 2,2\%, respectivement. D'autres animaux, comme les tortues d'eau et les amphibiens, sont des proies irrégulières $(<1 \%)$ et aucun vestige d'oiseaux a été trouvé. Le Circaète Jean-leBlanc est habituellement appelé comme un prédateur sténophagien où les serpents sont 
de loin le type de proie le plus important dans son régime alimentaire, et où, dans ce groupe taxonomique, elle se comporte comme un prédateur généraliste. Dans cette étude, cette prémisse a été testée en comparant l'abondance relative des espèces de serpents avec leur proportion dans la composition diététique de l'aigle, afin de savoir s'il y a aucune sélection de proies à l'égard des espèces de serpents dans cette région. Les résultats indiquent une «préférence» pour le Couleuvre à échelons et un «évitement» pour le groupe des serpents Macroprotodon brevis/Coronella girondica et peut-être pour la Couleuvre fer-à-cheval (Hemorrhois hippocrepis). L'évitement de la Couleuvre fer-à-cheval doit être indirect et lié à l'habitat, tandis que pour le groupe M. brevis/C. girondica il sera dû notamment à sa petite taille en particulier.

Mots-clés: Rapaces ; diète, ophiophagie ; Quercus suber and Quercus rotundifolia 


\section{Introduction}

The diet of the Short-toed Snake-eagle (hereinafter also called Snake-eagle) is well known and described in several parts of its breeding distribution in the Western Palearctic (BOUDOINT, 1953; GALUSHIN, 1959; THIOLLAY, 1968; CHOUSSY, 1973; BRUNO and PERCO, 1980; MEIR, 1980; GLUTZ VON BLOTZHEIM et al., 1989; CATTANEO and PETRETTI, 1992; del HOYO et al., 1994; VLACHOS and PAPAGEORGIOU, 1994; CAMPORA and ALBERTI, 1997; BAKALOUDIS et al., 1998; CRAMP, 1998; JEDRZEJEWSKA and JEDRZEJEWSKI, 1998; BÉRES, 2007; DARAWSHI, 2009; PETRETTI, 1988, 2012; BAKALOUDIS and VLACHOS, 2011a, 2011b; IVANOVSKY and SHAMOVICH, 2011; MAUMARY et al., 2013; MALAFOSSE and MALAFOSSE, 2015;), including some locations in Iberian Peninsula (VALVERDE, 1967; IRIBARREN and RODRÍGUEZ-ARBELOA, 1973; GARZÓN, 1974; AMORES and FRANCO, 1981; GIL and PLEGUEZUELOS, 2001; PLEGUEZUELOS and ONTIVEROS, 2011), but there is no information from Portugal so far. On the other hand, among all the works mentioned above, only a few studies have adequately quantified the proportions of each prey in the diet of this species and in many cases the total number of prey items identified was small or quite small. In fact, as far as we know, among more than 30 studies (including the present) in the entire range of the Short-toed Snake-eagle in the Palearctic and Indo-Malay regions only a dozen were based on more than 100 items and only less than half of those had worked more than 200 items (see citations above). In addition, few of all these studies were based on samples from a fairly number of nesting pairs and/or years. The remaining studies are more or less descriptive, fragmentary and not very representative.

The general opinion about the feeding ecology of this highly specialized top predator on reptiles, mostly snakes (IVANOVSKY, 1992; CRAMP, 1998; GIL and PLEGUEZUELOS, 2001; IVANOVSKY and SHAMOVICH, 2011), is that the eagle's feeding behavior is generalist with regard to the capture of snakes. So far, few studies have been addressed to determine snake species selection by the Shorttoed Snake-eagle. GIL and PLEGUEZUELOS (2001) found that the Short-toed Snake-eagle in Granada, Spain, consumes the species of snakes according to their availability in the wild and suggest that this eagle is a trophic generalist within upon the ophidians. Empirically, PETRETTI (1988) says that in Italy the Green Whip Snake (Hierophis viridiflavus) is the most common snake in the diet of the Snake-eagle and at the same time the more abundant, and MAUMARY et al. (2013) suggest that the Snake-eagle is able to adapt its behavior according to the more abundant or easily accessible species of snakes. Nevertheless, prey 
selection was already noted by BOUDOINT (1953), in Saint-Etienne, France, who stated that vipers and the Green Whip Snake were disproportionally captured according to his observations, the vipers being less captured and the Green Whip Snake more than its availability, and by VALVERDE (1967), in Doñana, Spain, which says that the Lataste's Viper (Vipera latastei) is captured much less often than expected.

Our premise in what concerns prey selection is that this stenophagic eagle should behave in our study area as mere generalist in their relative narrow range of prey, capturing snake species according to their availability.

During 1986 to 1995, a breeding population of this Short-toed Snake-eagle was surveyed in northern Alentejo, Portugal, in a landscape dominated by the traditional manmade parkland forests of evergreen oaks (Quercus suber and $Q$. rotundifolia). These kinds of woodland are non-intensive multipurpose ecosystems, unique of the southwestern part of the Iberian Peninsula, which are called as Montados in Portugal and as Dehesas in Spain, totaling $35.000-40.000$ $\mathrm{km}^{2}$, of which $8.000 \mathrm{~km}^{2}$ are found in Portugal, mainly in the Alentejo region (> 91\%) (OLEA and SAN MIGUEL-AYANZ, 2006; PINTO-CORREIA et al., 2011).

The Montados are extremely important in what concerns Portuguese forest products exportations (namely cork), regional economy, efforts against environmental and human desertification at the regional level, as well as for biodiversity, among other environmental goods and services (MARAÑON, 1988; OLEA and SAN MIGUEL-AYANZ, 2006; ONOFRE, 2007; SANDE SILVA, 2007; BELO et al., 2009; PINTO-CORREIA et al., 2011; PEREIRA et al., 2015). This type of agroforest ecosystem is listed in the EC 2000 Natura network as the Habitat "6310 Dehesas/Montados with evergreen Quercus spp." (EUROPEAN COMMISSION - DG ENVIRONMENT, 2007).

Since these forest ecosystems have a low human disturbance, Short-toed Snake-eagle is present all over the distribution of Montados in the country, reaching higher nesting densities in pure, dense and extensive cork oak groves (5 pairs $\left./ 100 \mathrm{~km}^{2}\right)$ (ONOFRE et al., 1999). Montados are a very important habitat for the conservation of this bird of prey in Portugal. 


\section{Materials and methods}

\section{Study area and land cover}

The study area is located in the counties of Mora and Avis, in the Alto Alentejo region, in south of Portugal, with the following WGS84 central coordinates: $38^{\circ} 58^{\prime} 37.96^{\prime \prime} \mathrm{N} ; 8^{\circ} 4^{\prime} 27.70^{\prime \prime} \mathrm{W}$. Large part of the study area is the same of the Natura 2000 Network Site of "Cabeção" (PTCON0029) (ICNF, 2016).

Woodland cover occupy almost $70 \%$ of the study area, being the cork oak groves largely predominant ( $\geq 50 \%$ of total area), followed by green oak groves $(10 \%)$ and pinewoods $(5 \%)$. Cork oak groves cover much of the northern half of the study area, as well as a strip in the west, while the green oaks groves and agricultural crops prevail further south and southeast. Rainfed cereal crops and fallow fields cover $12 \%$ of the area, irrigated crops $10 \%$ (mainly rice fields), and olive groves $5 \%$.

\section{Collection and analysis of food materials}

Nine pairs of Short-toed Snake-eagle were surveyed regularly between 1986 and 1995, comprising 38 breeding attempts. The nest sites were visited at least once a month between May and July, and pellets and prey remains were completely collected in the nests or on the ground under the nests or roosting trees nearby. Fresh prey remains found in the nests were identified in loco and left in it.

Each pellet or its respective fragments were kept in individual plastic bags and the entire set of pellets and prey remains found during the visit to the nest were collected in a large bag and labeled for further laboratory analysis.

Prey remains were identified down to the level of species or genus, with the exception of completely clean vertebral columns of snakes, which were classified only as unknown ophidians. Regarding pellet analysis, random samples were collected from each of them, mixed and the scales identified by LS. Scale reptile species were identified according to its morphology, taking into account the diagnostic characteristics of dorsal scales ( $c f$. GIL and PLEGUEZUELOS, 2001), and using a reference collection of scales of reptiles. Natrix species where pooled as well as M. brevis/C. girondica since it was not possible to set apart these species on the basis of scales present on pellets. Mammals' hair was identified to the order (Rodentia and Soricomorpha). After 
identification of prey items in prey remains and in pellets, all possible replications that could occur in adjoining visits were taken into account and excluded whenever appropriate.

The hair of small mammals was uncommon in pellets and insect remains were even rarer. Scales of Algerian Psammodromus (Psammodromus algirus), the most common Lacertidae species found in the study area, were conversely found with some frequency in pellets. However, most of these small animals detected in pellets can be considered a prey of the snakes seized by the eagle and, thus, a secondary prey item (CRAMP, 1998; GIL and PLEGUEZUELOS, 2001; BAKALOUDIS and VLACHOS, 2011a), since they are common prey of the snake species captured by the Snake-eagle in the study area (VALVERDE, 1967; FERICHE, 2015; PLEGUEZUELOS, 2015, 2017a, 2017b). One fresh headless Microtus cabrerae was found in one nest and at least one pellet was entirely composed by Algerian Psammodromus scales. Therefore, the capture of small mammals and lizards could not be disregarded regarding Snake-eagle foraging ecology, namely when some studies undoubtedly consider them to be effective prey (GARZÓN, 1974; MEIR, 1980; JEDRZEJEWSKA and JEDRZEJEWSKI, 1998; BAKALOUDIS and VLACHOS, 2011a, 2011b). No evidence was found on the capture of insects.

Finally, it must be stressed that the results of this study mainly reflect the prey brought to the nests and the nestling diet, since most of the material was collected in the nests and on the ground under the nest trees. However, GIL \& PLEGUEZUELOS (2001) did not find significant differences in the diet composition of nestlings and of adults, but rather in the size and weight of the preys, especially in snakes. BAKALOUDIS and VLACHOS (2011a) found the same, except in the proportions of some non-snake preys and in a few snake species (e.g. Dolichophis caspius), even if no statistical test on this respect has been done.

The description, techniques and calculations of the diet parameters follow MARTI et al. (2007), which also summarizes the biases of each technique used to study diet of birds of prey.

\section{Assessment of the relative abundance of snake species}

Between October of 2002 and July of 2003, 5 sections totaling $4.29 \mathrm{~km}$ of the irrigation canal that cross the study area in its southeast part were weekly surveyed to assess the rate of mortality of small to medium terrestrial 
vertebrates trapped in that canal (GODINHO and ONOFRE, 2013), and so also the snake species. This irrigation canal crosses several land uses, such as open evergreen oaks groves, olive groves and different agricultural crops (GODINHO and ONOFRE, 2013), mirroring the main foraging habitats of the Snake-eagle (N. ONOFRE, pers. data).

Like GIL and PLEGUEZUELOS (2001), we assumed that the reptile community in our study area has remained stable over the years (as well as other potential prey species of the Snake-eagle), since there were no significant changes in habitat between 1986 and 2003. We then assumed that the snake species and numbers counted in the irrigation canal represent a reasonable sampling of the snake community in the study area, thus allowing us to study the existence or not of selection of snake species by the Snake-eagle.

\section{Statistics methods}

Inferences about differences on the diet of Short-toed Snake-eagle and the relative abundance of snake species in the wild were made with unordered $R x$ $\mathrm{C}$ tables and the Chi-Square test. Still in relation to the diet, we also used some indices or measures of food preference suggested by KREBS (2014), using the software Krebs/WIN v. 0.94 (BRZUSTOWSKI, 1998). Spearman's rank correlation coefficient $\rho$ was used to study the association between the presence of the different species of snakes, small mammal's hair and Algerian Psammodromus scales in the pellets. Statxact ${ }^{\circledR}$ 5.0.3 statistical software package (Cytel Software Corporation $^{\odot}$ 1989-2001) was used.

\section{Results}

Diet composition of the Short-toed Snake-eagle

A total of 152 pellets and 52 prey remains were collected, and out of ca. 490 identified food items only 416 were considered after removing the most plausible replications. Data on pellets and prey remains were pooled together, and the results of the different methods are shown separately in the Table 1 pellets and prey remains alone and combined. The pellets consisted of scales of snakes and lizards, a few small mammals' hairs and insect remains, and no fragments of bones. In addition to the presence of Algerian Psammodromus 
scales in $50.3 \%$ of the pellets, $29.6 \%$ of all contained only one species of snake, $43.4 \% 2$ species and $27.0 \% 3$ species $(n=152)$.

Secondary prey, i.e. prey already present in the stomach of predator preys, is a recurrent and a particularly difficult problem to deal with when the diet assessment of a top bird of prey is based on pellet analysis. Mammals and lizards of small size, as well as insects, are referred as prey of the Short-toed Snake-eagle (THIOLLAY, 1968; GARZÓN, 1974; ALI and RIPLEY, 1978; BRUNO and PERCO, 1980; GLUTZ VON BLOTZHEIM et al., 1989; CRAMP, 1998). MEIR (1980), JEDRZEJEWSKA and JEDRZEJEWSKI (1998) and BAKALOUDIS and VLACHOS (2011a, 2011b), who studied the diet of the Snake eagle based only on pellets and prey remains, took into account insect/invertebrates as part of the diet composition.

In the present study, we found insect remains in only 7 out of 152 pellets $(4.5 \%)$, and representing only $1.7 \%$ of the total items found $(n=416)$ (Table 1$)$. The same applies to small lizards and small mammals that have also been found in small quantities. In fact, in the Iberian Peninsula, small lizards such as the Algerian Psammodromus (P. algirus) are important preys of the Montpellier Snake (Malpolon monspessulanus) and the Western False Smooth Snake (Macroprotodon brevis) (PLEGUEZUELOS, 2015; 2017b; SALVADOR, 2015). On the other hand, small mammals of genus Mus and Microtus are important prey of the Ladder Snake (Zamenis scalaris) (PLEGUEZUELOS, 2017a), and, to a large extent, also of the Montpellier snake (PLEGUEZUELOS, 2017b). Horseshoe Whip Snake (Hemorrhois hippocrepis) share almost equally small mammals and small lizards in its diet which form the bulk of its preys (FERICHE, 2015). Certainly insects, small mammals and reptiles could be considered almost of the time as secondary prey of the Snake-eagle, but in fact at least one fresh Cabrera's vole (Microtus cabrerae) was found in one nest and one pellet was entirely composed by Algerian Psammodromus scales. So, both prey species could not be definitively separated as a secondary prey in our study, at least in all cases.

Among the 152 pellets analyzed, small mammal's hair was found in 13 pellets $(7.6 \%)$, and scales of Algerian Psammodromus in 77 pellets $(50.3 \%)$, the first representing $3.1 \%$ and the last $18.5 \%$ of total preys items counted (Table 1 ). The test of Spearman's Coefficient of correlation shows that there is a strong association among the presence of Algerian Psammodromus and the snake scales $(\rho=0.6574 ; p<0.0001)$, in particularly with Montpellier Snake $(M$. monspessulanus $)(\rho=0.6994 ; p<0.0001)$ as well as with the Ladder Snake (Z. scalaris) $(\rho=0.5734 ; p<0.0001)$. Also statistical significant is the relationship between the presence of small mammal's hair and the snakes scales $(\rho=0.3048$; 
$p=0.0041)$, mainly of the Montpellier Snake $(\rho=0.3165 ; p=0.0032)$ and also of the smooth snakes (M. brevis/Coronella girondica) $(\rho=0.3018 ; p=0.0047)$. With regard to insects, no significant relationship was found between their remains and snakes in the pellets. This means that there is a strong chance that the majority of small lizards and small mammals will be prey of the snakes captured by the Snake-eagle, and not a direct prey.

Table 1 - Diet composition of Short-toed Snake-eagle in the "Montados" of Southwestern Iberian Peninsula

\begin{tabular}{|c|c|c|c|c|c|c|c|c|c|c|c|}
\hline \multirow{3}{*}{ Species } & \multicolumn{4}{|c|}{ Pellets } & \multicolumn{2}{|c|}{ Prey Remains } & \multicolumn{4}{|c|}{ Pellets + Prey Remains } & \multirow{3}{*}{$\begin{array}{c}\begin{array}{c}\text { Relative } \\
\text { frequency } \\
\text { in pellets } \\
(\%)\end{array} \\
\text { (1) - (2) }\end{array}$} \\
\hline & \multicolumn{2}{|c|}{$\begin{array}{l}\text { Absolute } \\
\text { Frequency } \\
\text { (No.) }\end{array}$} & \multicolumn{2}{|c|}{$\begin{array}{c}\text { Relative } \\
\text { frequency } \\
\text { in } \\
\text { percentage } \\
(\%) \\
\end{array}$} & \multirow[t]{2}{*}{$\begin{array}{c}\text { Absolute } \\
\text { Frequency } \\
\text { (No.) }\end{array}$} & \multirow[t]{2}{*}{$\begin{array}{c}\text { Relative } \\
\text { frequency } \\
\text { in } \\
\text { percentage } \\
(\%) \\
\end{array}$} & \multicolumn{2}{|c|}{$\begin{array}{l}\text { Absolute } \\
\text { Frequency }\end{array}$} & \multicolumn{2}{|c|}{$\begin{array}{c}\text { Relative } \\
\text { frequency } \\
\text { in } \\
\text { percentage } \\
(\%) \\
\end{array}$} & \\
\hline & $(1)$ & $-(2)$ & (1) & $-\quad(2)$ & & & $(1)$ & $-(2)$ & (1) - & $-(2)$ & \\
\hline AMPHIBIANS & 0 & -0 & 0.0 & $-\quad 0.0$ & 1 & 1.9 & 1 & -1 & $0.2-$ & -0.3 & 0.0 \\
\hline REPTILES & 393 & -317 & 94.5 & -99.1 & 46 & 88.5 & 439 & -363 & $93.8-$ & -98.2 & 100.0 \\
\hline TURTLES & 1 & -1 & 0.2 & -0.3 & 0 & 0.0 & 1 & -1 & $0.2-$ & -0.3 & 0.6 \\
\hline Mauremys leprosa & 1 & -1 & 0.2 & -0.3 & 0 & 0.0 & 1 & -1 & $0.2-$ & -0.3 & 0.6 \\
\hline LIZARDS & 91 & -15 & 21.9 & $-\quad 4.7$ & 3 & 5.8 & 94 & -18 & $20.1-$ & -4.8 & $59.9-19.7$ \\
\hline Timon lepidus & 0 & -0 & 0.0 & $-\quad 0.0$ & 3 & 5.8 & 3 & -3 & $0.6-$ & -0.8 & 0.0 \\
\hline Psammodromus algirus & 77 & -1 & 18.5 & -0.3 & 0 & 0.0 & 77 & -1 & $16.5-$ & -0.3 & $50.3-1.3$ \\
\hline Lacertidae und. & 14 & -14 & 3.4 & $-\quad 4.4$ & 0 & 0.0 & 14 & -14 & $3.0-$ & -3.8 & 9.6 \\
\hline SNAKES & 301 & -301 & 72.4 & -94.1 & 43 & 82.7 & 344 & -344 & $73.5-$ & -92.5 & 99.3 \\
\hline Hemorrhois hippocrepis & 7 & -7 & 1.7 & -2.2 & 1 & 1.9 & 8 & -8 & $1.7-$ & -2.2 & 4.5 \\
\hline Hemorrhois/Zamenis & 1 & -1 & 0.2 & -0.3 & 0 & 0.0 & 1 & -1 & $0.2 \quad-$ & -0.3 & 0.6 \\
\hline Zamenis scalaris & 98 & -98 & 23.6 & -30.6 & 6 & 11.5 & 104 & -104 & $22.2-$ & -28.0 & 65.6 \\
\hline Macroprotodon brevis & 0 & -0 & 0.0 & -0.0 & 1 & 1.9 & 1 & -1 & $0.2-$ & -0.3 & 0.0 \\
\hline Coronella/Macroprotodon & 16 & -16 & 3.8 & $-\quad 5.0$ & 0 & 0.0 & 16 & -16 & $3.4-$ & -4.3 & 10.2 \\
\hline Natris maura & 0 & -0 & 0.0 & -0.0 & 2 & 3.8 & 2 & -2 & $0.4 \quad-$ & -0.5 & 0.0 \\
\hline Natrix astreptophora & 0 & $\begin{array}{ll}- & 0 \\
\end{array}$ & 0.0 & $-\quad 0.0$ & 1 & 1.9 & 1 & -1 & $0.2-$ & -0.3 & 0.0 \\
\hline Natrix sp. & 47 & -47 & 11.3 & -14.7 & 3 & 5.8 & 50 & -50 & $10.7-$ & -13.4 & 31.2 \\
\hline Malpolon monspessulanus & 131 & -131 & 31.5 & -40.9 & 26 & 50.0 & 157 & -157 & $33.5-$ & -42.2 & 86.0 \\
\hline Colubridae und. & 1 & -1 & 0.2 & $\begin{array}{l}-\quad 0.3 \\
\end{array}$ & 0 & 0.0 & 1 & -1 & $0.2 \quad-$ & -0.3 & 0.6 \\
\hline Ophidia und. & 0 & $\begin{array}{ll}- & 0 \\
\end{array}$ & 0.0 & -0.0 & 3 & 5.8 & 3 & -3 & $0.6 \quad-$ & -0.8 & 0.0 \\
\hline MAMMALS & 16 & -3 & 3.8 & $-\quad 0.9$ & 5 & 9.6 & 21 & -8 & $4.5-$ & -2.2 & $8.9-1.3$ \\
\hline$\overline{\text { Erinaceus europaeus }}$ & 3 & -3 & 0.7 & $-\quad 0.9$ & 2 & 3.8 & 5 & -5 & $1.1-$ & -1.3 & 1.3 \\
\hline Lepus granatensis & 0 & $\begin{array}{l}-\quad 0 \\
\end{array}$ & 0.0 & $\begin{array}{l}-\quad 0.0 \\
\end{array}$ & 1 & 1.9 & 1 & $-\quad 1$ & $0.2 \quad-$ & $\begin{array}{l}-0.3 \\
\end{array}$ & 0.0 \\
\hline Microtus cabrerae & 0 & $\begin{array}{ll}- & 0 \\
\end{array}$ & 0.0 & -0.0 & 1 & 1.9 & 1 & -1 & $0.2-$ & -0.3 & 0.0 \\
\hline $\begin{array}{l}\text { Rodentia/Soricomorpha } \\
\text { und. }\end{array}$ & 13 & -0 & 3.1 & -0.0 & 1 & 1.9 & 14 & -1 & $3.0-$ & -0.3 & $7.6-0.0$ \\
\hline INSECTS & 7 & -0 & 1.7 & -0.0 & 0 & 0.0 & 7 & -0 & $1.5 \quad-$ & -0.0 & $4.5-0.0$ \\
\hline TOTAL & 416 & -320 & & & & & 467 & -371 & & & \\
\hline $\begin{array}{l}\text { Total Number of pellets } \\
\text { or Prey Remains }\end{array}$ & & & & & & & & & & & 152 \\
\hline
\end{tabular}

(1) Diet composition including also Insects, all Algerian Psammodromus and small mammals'hair. (2) Diet composition excluding presumed secondary prey. und. $=$ unidentified.

For these reasons, we chose to present in the same table of diet composition of the Snake-eagle two options: on the left side of each column (numbered (1)), the 
entire set of prey is presented, including all potential secondary prey detected; and, in the right side of each column (numbered (2)), the set of prey is shown except the most likely secondary preys (Table 1). However, in the latter case, some so-called secondary prey were included, such as the fresh Microtus mentioned above and the 3 remains of Ocellated lizard (Timon lepidus) that were found in three different nests, as well as the single pellet containing only scales of Algerian Psammodromus. The actual values of the relative frequency of each prey are within the displayed range, possibly closer to the column's right side.

According to Table 1, snakes represent 73.5 - $92.5 \%$ of the numeric frequency of food items in the Short-toed Snake-eagle diet composition, if we considered all items as prey, on one side, or if we exclude all potential secondary prey represented by insect remains, hairs of small mammals and the majority of scales of Algerian Psammodromus, on the other side.

As expected, snakes were the prevailing prey in the diet of the Snake-eagle, with Montpellier Snake being the most consumed one (33.5 - 42.2\%), followed by Ladder Snake (22.2 - 28.0\%), and the water snakes (Natrix spp.) (11.3 $14.2 \%)$ (Table 1). The Horseshoe Whip Snake (H. hippocrepis), a snake mainly diurnal (FERICHE, 2015), is one of the least consumed, representing less than $2.3 \%$ in the diet.

Lizards represent 20.1 - 4.8\% (mainly Algerian Psammodromus, but probably also some Ocellated lizards), and mammals 4.5 - 2.2\% (mainly Rodentia/Soricomorpha), with the smallest percentages taking place when all secondary preys are excluded of the diet composition. Other animals, such as pond turtles and amphibians, appear to be unusual prey (less than $2 \%$ ), and no remains of birds have been found in the pellets and nests.

\section{Composition and relative abundance of the snake assemblage in the study area}

Table 2 shows data on the vertebrates trapped in the irrigation canal mentioned above, with only the number of reptile species shown individually. Table 3 shows the abundance distribution of snake species found in the irrigation canal and in the Snake-eagle diet.

During March to July of 2003 (cf. GODINHO and ONOFRE, 2013), ninety snakes specimens where counted in the irrigation canal belonging to 7 species, the Montpellier Snake being the most common one (43.3\%; Table 3), and the Ladder Snake the second (21.1\%). The Viperine Water Snake (Natrix maura) is not uncommon, and is apparently more numerous than the Iberian Grass Snake 
(N. astreptophora), which agrees with SANTOS (2008a, 2008b) and PLEGUEZUELOS (2016) regarding the abundance of these two species in the Iberian Peninsula. The least frequent snake found in the irrigation canal is the Southern Smooth Snake (C. girondica), which was otherwise detected only once in the area by us. The only species of viper occurring in southern Portugal, the Lataste's Viper (Vipera latastei), was not found. This was expected, since this viper has a very scattered and fragmented distribution in the national territory, mainly limited to the mountains, and it is not referred for the region neither to almost all Alentejo district (BRITO, 2008).

Table 2 - Potential prey species trapped in the irrigation canal

\begin{tabular}{|l|c|c|}
\hline \multicolumn{1}{|c|}{ Species } & $\begin{array}{c}\text { Absolute } \\
\text { Frequency (No.) }\end{array}$ & $\begin{array}{c}\text { Relative } \\
\text { frequency in } \\
\text { percentage (\%) }\end{array}$ \\
\hline AMPHIBIANS (total) & $\underline{114}$ & $\underline{28.4 \%}$ \\
\hline REPTILES (total) & $\underline{108}$ & $\underline{26.9 \%}$ \\
Blanus cinereus & 13 & $0.7 \%$ \\
Chalcides striatus & 2 & $3.2 \%$ \\
Psammodromus algirus & $\underline{90}$ & $0.5 \%$ \\
Snakes (total) & 3 & $\underline{22.4 \%}$ \\
Hemorrhois hippocrepis & 1 & $0.7 \%$ \\
Coronella girondica & 19 & $0.2 \%$ \\
Zamenis scalaris & 13 & $4.7 \%$ \\
Macroprotodon brevis & 39 & $3.2 \%$ \\
Malpolon monspessulanus & 10 & $9.7 \%$ \\
Natrix maura & 5 & $2.5 \%$ \\
Natrix astreptophora & $\underline{179}$ & $1.2 \%$ \\
MAMMALS (total) & 401 & $\underline{44.6 \%}$ \\
\hline Grand Total & \\
\hline
\end{tabular}

Adapted from GODINHO and ONOFRE (2013). (Percentages calculated on the basis of total number of animals trapped in the irrigation canal).

The composition and abundance of snake species found in the canal seems to reflect fairly well what is described in LOUREIRO et al. (2008) about their distribution and abundance in Portugal and in particularly in the southern part of the country. The same seems to be true regarding the sharing of the relative abundance found in the Iberian Peninsula, where the Montpellier Snake is the most widespread and abundant snake (CRESPO and SAMPAIO, 1994; PLEGUEZUELOS, 2017b), followed by the Ladder Snake (CRESPO and SAMPAIO, 
1994; PLEGUEZUELOS, 2017a). The rather high relative numbers of the Western False Smooth Snake (M. brevis) found in the canal are a surprise, however, since according to CRESPO and SAMPAIO (1994), FERRAND de ALMEIDA (2008) and PLEGUEZUELOS (2015) this species is one of the scarcest ophidians in Portugal and the Iberian Peninsula.

Snake species selection by the Short-toed Snake-eagle

As it was not possible to separate several species in the pellet analysis, the two Natrix species and the two smooth snakes (M. brevis and C. girondica) had to be pooled into two respective groups (Table 3; Figure 1).

The results of the "Indices of Diet Preference" ( $c f$. KREBS, 2014) (Table 4) suggest the existence of prey selection by the Short-toed Snake-eagle regarding some snake species.

According to Table 4, all indices show a rather strong "avoidance" for the smooth snakes (M. brevis and C. girondica [Macr/Coro]), and, to some extent, also for the Horseshoe Whip Snake (Hemorrhois). Conversely, the results indicate a preference for the Ladder Snake, the most consumed snake after the Montpelier Snake in this study. For the remaining snake species (Montpelier and water snakes [Natrix sp.]), the indices values are above the hinge point but they are sufficient close to it to be considered indifferent in what concern "preference" or "avoidance" (Table 4).

Table 3 - Snake numbers trapped in the irrigation canal ("availability") and snake proportions in diet of the Short-toed Snake-eagle in the study area (absolute frequencies and percentages)

\begin{tabular}{|l|c|c|c|c|}
\hline \multirow{2}{*}{\multicolumn{1}{|c|}{ Snake species }} & \multicolumn{2}{c|}{ Irrigation Canal } & \multicolumn{2}{c|}{ Snake-eagle Diet } \\
\cline { 2 - 5 } & $\mathbf{N o .}$ & $\mathbf{\%}$ & No. & \% \\
\hline Hemorrhois hippocrepis & 3 & 3.33 & 8 & 2.36 \\
\hline Zamenis scalaris & 19 & 21.11 & 104 & 30.68 \\
\hline Macroprotodon/Coronella & 14 & 15.56 & 17 & 5.01 \\
\hline Malpolon monspessulanus & 39 & 43.33 & 157 & 46.31 \\
\hline Natrix spp. & 15 & 16.67 & 53 & 15.63 \\
\hline Total Ophidia & 90 & & 339 & \\
\hline
\end{tabular}

Percentages were calculated on the basis of the snakes total exclusively. 


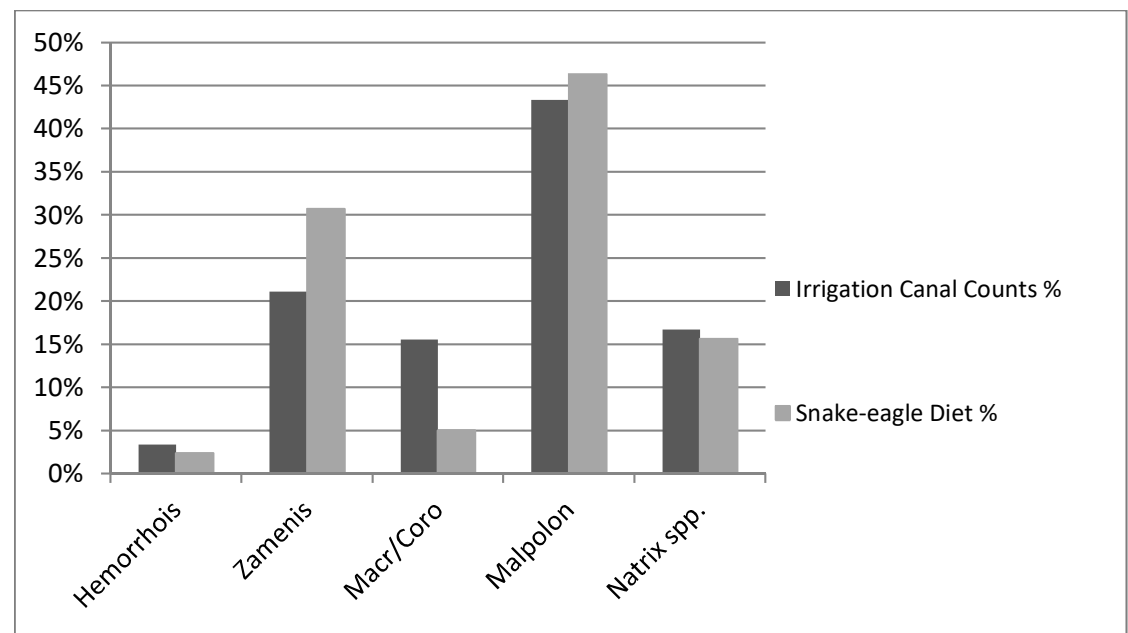

Figure 1 - Snake species availability distribution (irrigation canal counts) and snake proportions in the diet of the Short-toed Snake-eagle in the study area (percentages)

When comparing the abundance distribution of the five groups of snakes (Hemorrhois; Zamenis; Macr/Coro; Malpolon; Natrix spp.), there are statistical differences between the availability of the snake species in the study area (data from the Irrigation canal), and the relative frequency of snakes in the diet composition of the snake eagles $\left(\mathrm{X}^{2}=13.6546 ; \mathrm{df}=4 ; p=0.0085\right)$. In this case, the partial $X^{2}$ value of the Macr/Coro table cells are responsible for most part of the total $X^{2}\left(80 \%\right.$ of the total $X^{2}$ value of this test), and the Zamenis species for the second largest (c. $17 \%$ of the total $X^{2}$ ).

With two exceptions, all combinations of snake species between the irrigation canal and the eagle diet that included the Macr/Coro group were always significant $\left(\mathrm{X}^{2} ; \mathrm{df}=1-4 ; \mathrm{p}=0.0192-0.0003\right)$. These somewhat unexpected exceptions are the comparison within "Macr/Coro group plus Hemorrhois" $\left(\mathrm{X}^{2}=1.0784 ; \mathrm{df}=1 ; p=0.2991\right)$, and of the set "Hemorrhois; Macr/Coro; Natrix spp." ( $\left.\mathrm{X}^{2}=5.5288 ; \mathrm{df}=2 ; p=0.063\right)$. On the other hand, the comparison of "Macr/Coro plus Zamenis" in the canal and in the Snake-eagle diet resulted in the largest significant difference found $-X^{2}=12.9842 ; d f=1 ; p=$ 0.0003 . 
Table 4 - Results of the "Indices of Diet Preference" (cf. KREBS, 2014) of the Short-toed Snake-eagle in the study area

\begin{tabular}{|c|c|c|c|c|c|}
\hline \multirow{2}{*}{$\begin{array}{l}\text { Indices / Measures of } \\
\text { Diet Preferences }\end{array}$} & \multicolumn{5}{|c|}{ Species or Groups of Snake Species } \\
\hline & Hemorrhois & Zamenis & Macr/Coro & Malpolon & Natrix spp. \\
\hline \multirow[b]{2}{*}{ Forage Ratio $(\hat{w})(1)$} & 0.695 & 1.385 & 0.316 & 1.069 & 0.955 \\
\hline & Avoidance & Preference & Avoidance & $\begin{array}{c}\text { (Slight) } \\
\text { Preference/ } \\
\text { /"Virtually } \\
\text { indifference" }\end{array}$ & $\begin{array}{c}\text { (Slight) } \\
\text { Avoidance/ } \\
\text { /"Virtually } \\
\text { indifference" }\end{array}$ \\
\hline \multirow[b]{2}{*}{ Manly's Alpha (ai) (2) } & 0.157 & 0.313 & 0.072 & 0.242 & 0.216 \\
\hline & Avoidance & Preference & Avoidance & Preference & $\begin{array}{c}\text { (Slight) } \\
\text { Preference/ } \\
\text { /"Virtually } \\
\text { indifference" }\end{array}$ \\
\hline \multirow[b]{2}{*}{$\begin{array}{l}\text { Electivity }(\mathbf{R} 3)^{(3)} \\
\text { (normalized version } \\
\text { of the Forage Ratio) }\end{array}$} & -0.180 & 0.162 & -0.519 & 0.033 & -0.023 \\
\hline & Avoidance & Preference & Avoidance & $\begin{array}{c}\text { (Slight) } \\
\text { Preference/ } \\
\text { /"Virtually } \\
\text { indifference" }\end{array}$ & $\begin{array}{l}\text { (Slight) } \\
\text { Avoidance/ } \\
\text { /"Virtually } \\
\text { indifference" }\end{array}$ \\
\hline
\end{tabular}

(1) SAVAGE and WILLIAMS and MARSHALL cit. in KREBS (2014); (2) MANLY et al. cit. in KREBS (2014); (3) IVLEV cit. in LOEHLE and RITTENHOUSE (1982). For the selection indices above, values of "Forage Ratio" above 1.0 indicate preference, and less than 1.0 indicate avoidance, while for "Manly's Alpha" if ai is greater than $1 / \mathrm{m}$ ( $\mathrm{m}=$ total number of prey types) there is preference, and if less indicates avoidance (KREBS, 2014). Concerning the "Electivity" index, if R3 is greater than 0 there is preference, and if lesser than that means avoidance (LOEHLE and RITTENHOUSE, 1982). MACR/CORO = Macroprotodon/Coronella.

When comparing the abundance distribution of all groups and species of snakes but excluding the Macroprotodon/Coronella group, that is, considering only "Hemorrhois; Zamenis; Malpolon; Natrix spp.", no significant differences were detected between canal counts and $\operatorname{diet}\left(\mathrm{X}^{2}=2.004 ; \mathrm{df}=3 ; p=0.5716\right)$. The same happened with all other combinations of snake species or species' groups but the Macr/Coro (df 1-4; $p>0.25$ ).

\section{Discussion}

\section{Diet composition}

The diet composition of the population of Short-toed Snake-eagle in the study area is very similar to that found in Spain, where the Montpellier Snake is 
the most consumed species, followed by the Ladder Snake, and where all snakes comprise between 72 to almost $96 \%$ of the prey in its diets (VALVERDE, 1967; IRIBARREN and RODRÍGUEZ-ARBELOA, 1973; AMORES and FRANCO, 1981; GIL and PLEGUEZUELOS, 2001). With regard to the proportion of snakes in the diet of this eagle, our data fall in the range of percentage of snakes found in almost all quantitative studies on diet conducted in the breeding distribution area of this Snake-eagle from west (Iberian Peninsula) to the east (European Russia and central Asia) (BOUDOINT, 1953; GAVRINA cit. in GALUSHIN, 1959; VALVERDE, 1967; AMORES and FRANCO, 1981; CHOUSSY, 1973; PETRETTI, 1988, 2012; MEIR, 1980; CHIAVETTA cit. in CATTANEO and PETRETTI, 1992; IVANOVSKY, 1992; VLACHOS and PAPAGEORGIOU, 1994; CAMPORA and ALBERTI, 1997; BAKALOUDIS et al., 1998; JEDRZEJEWSKA and JEDRZEJEWSKI, 1998; GIL and PLEGUEZUELOS, 2001; BÉRES, 2007; BAKALOUDIS and VLACHOS, 2011a, 2011b; IVANOVSKY and SHAMOVICH, 2011; BUREAU and MAYAUD cit. in MAUMARY et al., 2013; MAUMARY et al., 2013; MALAFOSSE and MALAFOSSE, 2015). Respecting the lizards consumed, the same is true, with some exceptions, such in Greece, Poland and India, where the proportion of lizards is higher (GAVRINA cit. in GALUSHIN, 1959; VLACHOS and PAPAGEORGIOU, 1994; BAKALOUDIS et al., 1998; JEDRZEJEWSKA and JEDRZEJEWSKI, 1998; BAKALOUDIS and VLACHOS, 2011a; MORI et al., 2017). The most extreme exception respects the population of Short-toed Snake-eagle in the Judean Slopes, Israel, where small mammals (Rodentia) represent $96 \%$ of the diet and reptiles only $4 \%$ (DARAWSHI, 2009). Leaving this unique case aside, the proportion of the different classes of prey is quite similar to that of the remaining diets across the eagle's distribution area, changing only the species of the preys according to the different types of distribution of groups of reptiles and their richness (BRUNO and PERCO, 1980; BROWN and AMADON, 1989; GLUTZ VON BLOTZHEIM et al., 1989; CRAMP, 1998; SILLERO et al., 2014). For this reason, the composition in species of reptiles and, in particularly, of snakes of the Iberian diets of the Short-toed Snake-eagle populations (VALVERDE, 1967; IRIBARREN and RODRÍGUEZ-ARBELOA, 1973; AMORES and FRANCO, 1981; GIL and PLEGUEZUELOS, 2001; present study) is fairly distinct from the diet of the other European and Asiatic populations, mirroring the "CR2 distribution type of grouped reptile species" described by SILLERO et al. (2014) for this most western part of Europe. 
Snake species selection

According with the "Indices of Diet Preference" results (Table 4), the population of Short-toed Snake-eagle in the Montados of this region of Iberian Peninsula seems to "avoid" some species of snakes, "prefer" others and to capture another according to its availability in the study area.

The "Indices of Diet Preference" point out that the smooth snakes group ( $M$. brevis/C. girondica) is "avoided" or "not preferred" ( $\hat{\mathrm{w}}=0.316$; ai $=0.072 ; \mathrm{R} 3=$ 0.519) (Table 4). On the other hand, the results of the Chi-square test show statistical differences between canal counts and diet frequencies when comparing the distributions of all snake species (Hemorrhois; Zamenis; Macr/Coro; Malpolon; Natrix spp. $)\left(\mathrm{X}^{2}=13.6546 ; \mathrm{df}=4 ; p=0.0085\right)$. The partial chi-square values of the Macr/Coro cells represents $80 \%$ of the total Chi-square value of the test, indicating that this group of smooth snakes is the main contributor to the statistical difference. These statistical differences are no longer found when only the Macr/Coro group is excluded $\left(\mathrm{X}^{2}=2.004 ; \mathrm{df}=3 ; p\right.$ $=0.5716)$. In addition, with the exception of two combinations, all tests between canal counts and diet frequencies in which the Macr/Coro group is included resulted in significant differences $(p<0.05)$. Two reasons can justify this said "avoidance": body size and circadian activity. Both smooth snakes are mainly nocturnal and crepuscular and reach rather small sizes (C. girondica: Avg. $=496$ mm; Max. $=800$ mm; M. brevis: Avg. 338.7 mm [148-598 mm]; Max. $=598$ or 650 $\mathrm{mm}$ ) (CRESPO and SAMPAIO, 1994; PLEGUEZUELOS, 2015; SANTOS and PLEGUEZUELOS, 2015). Since it is not uncommon to see the Short-toed Snakeeagle hunting during the sunset or even well after it (GALUSHIN, 1980; OJALVO, 1998; BÉRES, 2007; N. ONOFRE, pers. obs.), the Snake-eagle could take advantage of twilight to capture these snakes. However, considering the principles of foraging theory ( $c f$. STEPHENS and KREBS, 1987) and the Snakeeagle preference for snakes with sizes within 600-1200 mm (GIL and PLEGUEZUELOS, 2001; BÉRES, 2007; BAKALOUDIS and VLACHOS, 2011a; PETRETTI, 2012), the Snake-eagle may prefer to capture snakes of larger size (e.g. the Ladder Snake), and thus disregard the smaller smooth snakes.

The results of the diet preference indices for the Horseshoe Whip Snake also show "avoidance" for this species $(\hat{\mathrm{w}}=0.695 ;$ ai $=0.157 ; \mathrm{R} 3=-0.180)$, although indices values be rather weaker than for the smooth snakes. The Horseshoe Whip Snake is essentially diurnal and quite large (Avg. $891.3 \mathrm{~mm}$ [237-1.660 $\mathrm{mm}$ ) (FERICHE, 2015) - thus being a tempting prey for the Snake-eagle, but it shows a strong anthropophilia and propensity for urban environments 
(CRESPO and SAMPAIO, 1994; FERICHE, 2015), environments that the Snakeeagle really avoids. This could explain the results of the "Indices of Diet Preference" for this species of snake, the so-called "avoidance". However, no Chi-square test results support this, maybe because the samples sizes and the difference between the proportions of snakes in the irrigation canal and in the diet were too small ( $c f$. tables 3 and 4; Figure 1). The apparent smaller quantity of Horseshoe Whip snakes captured by the Snake-eagle in relation to its availability should be rather a result of habitat avoidance and not prey species avoidance.

Concerning the Ladder Snake, the results of the "Indices of Diet Preference" indicate that there is a "preference" for this snake by the Snake-eagle $(\hat{\mathrm{w}}=1.385$; ai $=0.313 ; \mathrm{R} 3=0.162$ ). This is somewhat unpredicted, because we would expected that this snake would be captured according to its availability, as did found GIL and PLEGUEZUELOS (2001) in Granada, Spain, or "avoided", since it does not have a really daylight activity (CRESPO and SAMPAIO, 1994; PLEGUEZUELOS, 2017a). The results of the Chi-Square test, which compared the availability distributions of snake species and their proportions in the diet, do not directly support the results of the diet preference indices for this snake species. Only two comparisons with the $\mathrm{X}^{2}$ test favor this preference for the Ladder Snake by the Snake-eagle: i) Concerning the set "Hemorrois, Zamenis, Macr/Coro, Malpolon, Natrix spp", the Zamenis species is the second largest contributor to the significant difference between the relative abundance of snakes in the study area and in the diet (the partial chi-square of Zamenis cells represents $17 \%$ of the total $X^{2}$; see Results); ii) The comparison of the set "Zamenis, Macr/Coro" resulted in the largest significant difference among all comparisons. This snake is mainly nocturnal and twilight, but could be also diurnal during the less hot months (CRESPO and SAMPAIO, 1994; CHEYLAN cit. in PLEGUEZUELOS and BRITO, 2008; PLEGUEZUELOS, 2017a). Moreover, the Ladder Snake is one of the largest snakes in the Iberian Peninsula (819.8 \pm 146.0

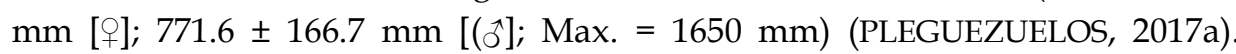
Therefore, in addition to the specimens that the Short-toed Snake-eagle could capture during the daylight, it must take advantage of the beginning of the predominantly nocturnal activity of the Ladder Snake during the sunset and dusk, in order to search primarily for this snake, the largest one active at this time of day.

Finally, the Montpellier Snake and the two water snakes (Natrix spp.) seem to be consumed according to its availability, since the values results of the "Indices of Diet Preference" are close to the central value of indifference (see 
Table 4), and the results of the Chi-Square tests point out for no statistical difference. In this regard, when considering only the Montpellier and the water snakes species the Chi-Square test indicate no difference between their relative abundance in the wild and their proportion in the diet of the Snake-eagle $\left(X^{2}=\right.$ $0.1082 ; \mathrm{df}=1 ; p=0.8264)$. These three snake species are mainly diurnal (CRESPO and SAMPAIO, 1994; SALVADOR and MARCO, 2017) with sizes falling within the range of the preferred snake size of the Snake-eagle (GIL and PLEGUEZUELOS, 2001; BÉRES, 2007; BAKALOUDIS and VLACHOS, 2011a; PETRETTI, 2012).

\section{Conclusions}

The diet composition of the Short-Toed Snake-eagle in the Montados of Southwestern Iberian Peninsula is very similar to the diet of the other populations studied in the neighboring Spain, and the proportions of the different taxonomic groups of prey in its diet are within the findings of the majority of the studies on the diet of this species in the Palearctic. Reptiles and snakes, in particular, are by far the predominant prey and, despite being already a stenophagic species, the Snake-eagle still exhibits selective hunting behavior in relation to snake species. The smooth snakes Coronella girondica and Macroprotodon brevis are "avoided", probably due to their small size, but their nocturnal activity could also contribute. The Horseshoe Whip Snake seems to be "avoided" as well, but this should result rather from habitat avoidance instead of the snake species avoidance herself. The Ladder Snake is the only species that appears to be captured in greater proportion than its availability, against our initial expectations.

\section{Acknowledgments}

First of all, I shall dedicate this paper to LUÍS SAMPAIO, my co-author and a promising herpetologist who passed away too soon, shortly after he finished the identification of snake species in pellets, a guy that I never met personally. I am grateful to all the people who accompanied or assisted me in the field, local young ones and college students. I am also grateful to Ana Teresa Chinita for the comments to the manuscript and to Isabel Carvalho Santos who revised the English writing. This work was supported in large part by the Fundação para a 
Ciência e Tecnologia (Portuguese Foundation for Science and Technology), exJNICT, Projecto PEAM/C/CNT/4/91, "Bases para o ordenamento do habitat para a conservação das aves de rapina florestais" [Bases for habitat management for the conservation of forest birds of prey].

\section{References}

ALI, A., RIPLEY, S.D., 1978. Handbook of the Birds of India and Pakistan Vol 1: Divers to Hawks. Together with those of Bangladesh, Nepal, Bhutan and Sri Lanka. 2nd Ed. Oxford University Press. London, New York, 382 pp.

AMORES, F., FRANCO, A., 1981. Alimentation et écologie du Circaéte Jean-Ie-Blanc dans le sud de l'Espagne. Alauda 49: 59-61.

BAKALOUDIS, D.E., VLACHOS C.G., 2011a. Feeding habits and provisioning rate of breeding short-toed eagles Circaetus gallicus in northeastern Greece. Journal of Biological Research-Thessaloniki 16: 166-176.

BAKALOUDIS, D.E., VLACHOS, C.G., 2011b. Ecology and conservation of the short-toed eagle (Circaetus gallicus) in NE Greece. In ZUBEROGOITIA, I., MARTíNEZ, J.E., (Eds.). Ecology and Conservation of European Forest-Dwelling Raptors. Departamento de Agricultura de la Diputación Foral de Bizkaia, Bilbao, pp. 211-218.

BAKALOUDIS, D.E., VLACHOS, C.G., HOLLOWAY, G.J., 1998. Habitat use by short-toed eagles Cicaetus gallicus and their reptilian prey during the breeding season in Dadia Forest (north-eastern Greece). J. App. Ecol. 35: 821-828.

BELO, C., SILVA PEREIRA, M., MOREIRA, A.C., SEITA COELHO, I., ONOFRE, N., AMBRÓSIO, A.P., 2009. Capítulo 8: Montado. In Ecossistemas e Bem-Estar Humano. Avaliação para Portugal do Millennium Ecosystem Assessment: State of the Assessment Report. PEREIRA, H.M, DOMINGOS, T, VICENTE, L, PROENÇA, V., (Coords.). Fundação da Faculdade de Ciências de Lisboa da U.L. \& Escolar Editora, Lisboa, pp. 251-293.

BÉRES, I., 2007. A Kígyászölyv (Circaetus gallicus) viselkedési és fészkelési szokásai a Zemplénihegységben [Behaviour and breeding habits of the Short-toed Eagle in the Zemplénmountains] - M. Sc. Thesis - Debrecen, 56 pp.

BOUDOINT, Y., 1953. Etude de la biologie du Circaète Jean-le-Blanc. Alauda 21: 86-112.

BRITO, J.S., 2008. Vipera latastei Boscá, 1878. Víbora-cornuda. In LOUREIRO, A., FERRAND de ALMEIDA, N., CARRETERO, M.A., PAUlO, O.S., (Eds.). Atlas dos Anfíbios e Répteis de Portugal. Instituto da Conservação da Natureza e da Biodiversidade, Lisboa, pp. 182-183.

BROWN, L., AMADON, D., 1989. Eagles, Hawks and Falcons of the World. 2 vols. The Wellfleet Press, Secaucus, NJ, 945 pp.

BRUNO, S., PERCO, F., 1980. Considerazioni ecologiche ed etologiche sul Biancone (Circaetus gallicus). Natura Bresciaana, Ann. Mus. Civ. St. Nat. - Brescia 17: 124-210. 
BRZUSTOWSKI, J., 1998. Krebs/WIN. Krebs Ecological Methodology for Windows (Version 0.94 --- 3 Mar. 1998) Alberta. Canada. http://www2.biology.ualberta.ca/jbrzusto/ ftp/krebs/index.html.

BUREAU, L., MAYAUD, N., 1953. Observations du Circaète Jean-le-Blanc dans l'ouest de la France. Alauda 21: 115-119.

CAMPORA M., ALBERTI, S., 1997. Osservazioni sulla dieta del Biancone (Circaetus gallicus) in un'area dell'Appennino Settentrionale. Riv. Piem. St. Nat. 18: 233-239.

CATTANEO, G., PETRETTI F., 1992. Biancone - Circaetus gallicus (Gmelin, 1788). In BRICHETTI, P., De FRANCESCHI, P., BACCETTI, N., (Eds.). Fauna d'Italia, XXIX. Aves I. Calderini, Bologna, pp. 520-526.

CHOUSSY, D., 1973. Observations sur le Circaète Jean-le-Blanc. Nos Oiseaux 32: 83-89.

CRAMP, S., 1998. The Complete Birds of the Western Palearctic CD-ROM. Version 1.0. Oxford University Press 1998, including Database Right Software c Optimedia 1998.

CRESPO, E.G., SAMPAIO, L., 1994. As Serpentes de Portugal. Instituto da Conservação da Natureza, Lisboa, 40 pp.

DARAWSHI, S., 2009. The ecology of the Short-toed Eagle (Circaetus gallicus) in the Judean Slopes. Israel. Graduate Thesis Research report to R.S.G with Additional Aspects of Conservation and Education between Three Continents. Department of Evolution, Systematics and Ecology. The Hebrew University of Jerusalem. Jerusalem, 17 pp.

del HOYO, J., ELLIOTT, A., SARGATAL, J., 1994. Handbook of the Birds of the World - Volume 2: New World Vultures to Guineafowl. Lynx Edicions, Barcelona, 638 pp.

EUROPEAN COMMISSION - DG ENVIRONMENT, 2007. Interpretation Manual of European Union Habitats. EUR 27, July 2007, European Commission, DG Environment, Brussels, 144 pp.

FERICHE, M., 2015. Culebra de herradura - Hemorrhois hippocrepis. In SALVADOR, A., MARCO, A., (Eds.). Enciclopedia Virtual de los Vertebrados Españoles. Museo Nacional de Ciencias Naturales, Madrid. http://www.vertebradosibericos.org/.

FERRAND de ALMEIDA, N., 2008. Macroprotodon cucullatus (Geoffroy Saint-Hilaire, 1827). Cobra-de-capuz. In LOUREIRO, A., FERRAND de ALMEIDA, N., CARRETERO, M.A., PAUlO, O.S., (Eds.). Atlas dos Anfíbios e Répteis de Portugal. Instituto da Conservação da Natureza e da Biodiversidade, Lisboa, pp. 174-175.

GALUSHIN, V.M., 1959. Некоторые данные по гнездованию змееяда Circaetus gallicus в Рязанской области. [Some data about breeding of the Short-toed Eagle Circaetus gallicus in Ryazan region]. Русский орнитологический журнал 2016, Том 25, Экспресс-выпуск, (Переиздание) [Russian Ornithological Journal 2016, 25, Express Issue, (Reprint)] 1361: 4297-4301.

GALUSHIN, V.M., 1980. Хищные птицы леса [Birds of Prey of Forest]. Лесная промышленность [Forest industry]. 160 pp.

GARZÓN, J., 1974. Contribución al estudio del status, alimentación y protección de las Falconiformes en España central. Ardeola 19: 279-330. 
176 Onofre, N. and Sampaio, L.

GIL, J.A., PLEGUEZUELOS, J.M., 2001. Prey and prey-size selection by the short-toed eagle (Circaetus gallicus) during the breeding season in Granada (south-eastern Spain). J. Zool., Lond. 255: 131-137.

GLUTZ VON BLOTZHEIM, U.N., BAUER, K.M., BEZZEL, E., 1989. Handbuch der Vögel Mitteleuropas, Band 4. Falconiformes. AULA-Verlag Visbaden, 943 pp.

GODINHO, S., ONOFRE, N., 2013. Mortalidade de Vertebrados Terrestres no Canal do Vale da Ribeira de Seda (Cabeção - Alto Alentejo - Portugal). Silva Lusitana 21: 21-42.

ICNF, 2016. BIODIVERSIDADE/Natura 2000/Plano Setorial RN 2000/Cartografia. http://www.icnf.pt/portal/naturaclas/rn2000/resource/docs/rn-plan-set/sic-lista.

IRIBARREN, J.J., RODRÍGUEZ-ARBELOA, A., 1973. Observaciones en un nido del Águila Culebrera (Circaetus gallicus), Navarra 1972. Ardeola 19: 101-106.

IVANOVSKY, V., 1992. Трофические связи редких хищных птиц Белорусского Поозерья. [Trophic relations of rare birds of prey Belarusian Lakeland]. Оттиск, 173: 66. [The reprint, 173: 66.].

IVANOVSKY, V., SHAMOVICH., D., 2011. Ecology of Short-toed Eagle in Belarussian Poozerie. Berkut 20: 81-89.

JEDRZEJEWSKA, B., JEDRZEJEWSKI, W., 1998. Predation in vertebrate communities. The Białowieża Primeval Forest as a case study. Ecological Studies 135, Springer-Verlag, Berlin-Heidelberg-New York, 450 pp.

KREBS, C.J., 2014. Ecological Methodology, $3^{\text {rd }}$ ed. (in prep.). Chapters revised to date (14 March 2014) are available to download for evaluation and review. http://www.zoology.ubc.ca/ krebs/books.html.

LOEHLE, G., RITTENHOUSE, L.R., 1982. An analysis of forage preferences Indices. Journal of Range Management 35: 316-319.

LOUREIRO, A., 2008. Coronella girondica (Daudin, 1803). Cobra-lisa-bordalesa. In LOUREIRO, A., FERRAND de ALMEIDA, N., CARRETERO, M.A., PAULO, O.S., (Eds.). Atlas dos Anfibios e Répteis de Portugal. Instituto da Conservação da Natureza e da Biodiversidade, Lisboa, pp. 170-171.

LOUREIRO, A., FERRAND de ALMEIDA, N., CARRETERO, M.A., PAUlO, O.S., (Eds.). 2008. Atlas dos Anfíbios e Répteis de Portugal. Instituto da Conservação da Natureza e da Biodiversidade,Lisboa, $257 \mathrm{pp}$.

MARAÑON, T., 1988. Agro-Sylvo-Pastoral Systems in the Iberian Peninsula: Dehesas and Montados. In Multi-Species Grazing and Marketing. Rangelands 10, Society for Range Management, 255-258 pp.

MARTI, C.D., BECHARD, M., JAKSIC, F.M., 2007. Chapter 8. Food Habits. In Bird, D., Bildstein, K., (Eds.). Raptor Research and Management Techniques Manual. Raptor Research Foundation, Hancock House Publishers, Blaine, WA, U.S.A, pp. 129-151.

MALAFOSSE, J.-P., MALAFOSSE, I., 2015. Suivi des Rapaces forestiers en Lozère et dans le Parc National des Cévennes: Le Circaète Jean-le-Blanc, résultats pour 2015. Rapport interne C.R.B.P.O./P.N.C., 10 pp. 
MAUMARY, L., DUPERREX, H., CLOUTIER, J., VALLOTTON, L., 2013. Première nidification du circaète Jean-le-Blanc Circaetus gallicus en Suisse. Observations sur la biologie de reproduction, en particulier le régime alimentaire. Nos oiseaux 60: 3-24.

MEIR, B., 1980. The Biology and Population Ecology of the Short-toed Eagle (Circaetus gallicus gallicus) in the Judean hills, Israel. MSc Thesis, Tel-Aviv University, Israel. (In Hebrew with English summary).

MORI, D., VYAS, R., UPADHAYAY, K., 2017. Breeding biology of the Short-toed Snake Eagle Circaetus gallicus. Indian BIRDS 12: 149-156.

OJALVO, J. A., 1998. Chasse crepusculaire du circaete Jean-le-Blanc Circaetus gallicus. Nos Oiseaux 45: 245.

OLEA, L., SAN MIGUEL-AYANZ, A., 2006. The Spanish dehesa. A traditional Mediterranean silvopastoral system linking production and nature conservation. Opening Paper. In LlOVERAS, J., GONZÁlEZ-RODRÍGUEZ, A., VÁZQUEZ-YAÑEZ, O., PIÑEIRO, J., SANTAMARÍA, O., OLEA, L., POBLACIONES, M.J., (Eds.). 21 st General Meeting of the European Grassland Federation. Badajoz (Spain). April 2006. Sociedad Española para el Estudio de los Pastos (SEEP), Madrid, pp. 3-13.

ONOFRE, N., 2007. Capítulo II.2. A fauna dos montados de azinho, pp. 131-159. In SANDE SILVA, J., (Coord. Ed.). Os MONTADOS. Muito para além das árvores. Colecção "Árvores e Florestas de Portugal", No 03. Fundação Luso-Americana, Jornal Público, Liga para a Protecção da Natureza (LPN). Lisboa.

ONOFRE, N., CAPELO, M., FARIA, P., TEIXEIRA, F., CORTEZ, P., BLANCO, H., CONDENÇO, V., CRUZ, C., PINHEIRO, A., ROSA, G., CLARO, J., VENADE, D., ALMEIDA, J.L., PAIS, M., SAFÁRA, J., CANGARATO, R., PEÇA, C., PEREIRA, D., 1999. Estimativas de abundância de aves de rapina diurnas em habitats florestais e agrícolas em Portugal Continental. In BEJA P, CATRY P,. MOREIRA F., (Eds.). "Actas do II Congresso de Ornitologia da SPEA". 30 Out - 1 Nov 1999. Univ. Faro, Campus de Gambelas, Faro, pp. 177-179.

PEREIRA, P., GODINHO, C., ROQUE, I., RABAÇA, J.E., 2015. O montado e as aves: boas práticas para uma gestão sustentável. LabOr - Laboratório de Ornitologia. ICAAM, Universidade de Évora, Câmara Municipal de Coruche, Coruche, 413 pp.

PETRETTI, F., 1988. Notes on the behaviour and ecology of the Short-toed Eagle in Italy. Gerfaut 78: 261-286.

PETRETTI, F., 2012. Comportamento alimentare del biancone Circaetus gallicus in Maremma. 2a Giornata Romana di Ornitologia, Roma, 24 Novembre 2012.

PINTO-CORREIA, T, RIBEIRO, N., SÁ-SOUSA, P., 2011. Introducing the montado, the cork and holm oak agroforestry system of Southern Portugal. Agrofor. Syst. 82: 99-104.

PLEGUEZUELOS, J.M., 2015. Culebra de cogulla occidental - Macroprotodon brevis. In SALVADOR, A., MARCO, A., (Eds.) Enciclopedia Virtual de los Vertebrados Españoles. Museo Nacional de Ciencias Naturales, Madrid. http://www.vertebradosibericos. org/. 
178 Onofre, N. and Sampaio, L.

PLEGUEZUELOS, J.M., 2016. Culebra de collar mediterránea - Natrix astreptophora. In SALVADOR, A., MARCO, A., (Eds.). Enciclopedia Virtual de los Vertebrados Españoles. Museo Nacional de Ciencias Naturales, Madrid. http://www.vertebradosibericos. org/.

PLEGUEZUELOS, J.M., 2017a. Culebra de escalera - Zamenis scalaris. In SALVADOR, A., MARCO, A., (Eds.) Enciclopedia Virtual de los Vertebrados Españoles. Museo Nacional de Ciencias Naturales, Madrid. http:/ / www.vertebradosibericos.org/.

PLEGUEZUELOS, J.M., 2017b. Culebra bastarda - Malpolon monspessulanus. SALVADOR, A. MARCO, A., (Eds.). In Enciclopedia Virtual de los Vertebrados Españoles. Museo Nacional de Ciencias Naturales, Madrid. http://www.vertebradosibericos.org/.

PLEGUEZUElOS, J.M., SANTOS, X., 2002. Vipera latasti Boscá, 1878. Víbora hocicuda. In PLEGUEZUELOS J. M., MÁRQUEZ R., LIZANA M., (Eds.) Atlas y Libro Rojo de los Anfibios y Reptiles de España. Dirección General de Conservación de la Naturaleza-Asociación Herpetologica Española (2 $2^{\mathrm{a}}$ impresión), Madrid, pp. 299-301.

PLEGUEZUELOS, J.M., BRITO, J.C., 2008. Elaphe scalaris (Schinz, 1822) Cobra-de-escada. In LOUREIRO, A., FERRAND de ALMEIDA, N., CARRETERO, M.A., PAULO, O.S., (Eds.). Atlas dos Anfíbios e Répteis de Portugal. Instituto da Conservação da Natureza e da Biodiversidade, Lisboa, pp. 172-173.

PLEGUEZUELOS, J.M., ONTIVEROS, D., 2011. Diet and prey selection by the short-toed eagle. In ZUBEROGOITIA, I., MARTÍNEZ, J.E., (Eds.). Ecology and conservation of European forest-dwelling raptors. Departamento de Agricultura de la Diputacion Foral de Bizkaia, Bilbao, pp. 219-225.

PLEGUEZUElos J.M., MÁRQUEZ R., LIZANA M., (Eds.) 2002. Atlas y Libro Rojo de los Anfibios y Reptiles de EspañaI. Dirección General de Conservación de la NaturalezaAsociación Herpetologica Española (2 ${ }^{\mathrm{a}}$ impresión), Madrid, 587 pp.

SANDE SILVA, J., (Coord. Ed.). 2007. Os MONTADOS. Muito para além das árvores. Colecção "Árvores e Florestas de Portugal", No 03. Fundação Luso-Americana, Jornal Público, Liga para a Protecção da Natureza (LPN), Lisboa, 247 pp.

SANTOS, X., 2008a. Natrix maura (Linnaeus, 1758). Cobra-de-água-viperina. In LOUREIRO, A., FERRAND de ALMEIDA, N., CARRETERO, M.A., PAULO, O.S., (Eds.). Atlas dos Anfíbios e Répteis de Portugal. Instituto da Conservação da Natureza e da Biodiversidade, Lisboa, pp. 176-177.

SANTOS, X., 2008b. Natrix natrix (Linnaeus, 1758). Cobra-de-água-de-colar. In LOUREIRO, A., FERRAND de ALMEIDA, N., CARRETERO, M.A., PAULO, O.S., (Eds.). Atlas dos Anfíbios e Répteis de Portugal. Instituto da Conservação da Natureza e da Biodiversidade, Lisboa, pp. 178-179.

SANTOS, X., 2015. Culebra viperina - Natrix maura. In SALVADOR, A., MARCO, A. (Eds.). Enciclopedia Virtual de los Vertebrados Españoles. Museo Nacional de Ciencias Naturales, Madrid. http://www.vertebradosibericos.org/. 
SANTOS, X., PLEGUEZUELOS, J.M., 2015. Culebra lisa meridional - Coronella girondica. In SALVADOR, A., MARCO, A., (Eds.). Enciclopedia Virtual de los Vertebrados Españoles. Museo Nacional de Ciencias Naturales, Madrid. http://www.vertebradosibericos. org/.

SALVADOR, A., 2015. Lagartija colilarga - Psammodromus algirus. In SALVADOR, A., MARCO, A., (Eds.). Enciclopedia Virtual de los Vertebrados Españoles. Museo Nacional de Ciencias Naturales, Madrid. http:/ / www.vertebradosibericos.org/.

SALVADOR, A., MARCO, A., (Eds.). 2017. Enciclopedia Virtual de los Vertebrados Españoles. Museo Nacional de Ciencias Naturales, Madrid. http://www.vertebradosibericos. org/.

SILLERO, N., CAMPOS, J., BONARDI, A., CORTI, C., CREEMERS, R., CROCHET, P.-A., ISAILOVIC', J.C., DENOËL, M., FICETOLA, G.F., GONÇALVES, J., KUZMIN, S., LYMBERAKIS, P., de POUS, P., RODRÍGUEZ, A., SINDACO, R., SPEYBROECK, J., TOXOPEUS, B., VIEITES, D.R., VENCES, M., 2014. Updated distribution and biogeography of amphibians and reptiles of Europe. Amphibia-Reptilia 35: 1-31.

SIMMONS, R.E., AVERY, D.M., AVERY, G., 1991. Biases in diets determined from pellets and remains correction factors for a mammal and bird eating raptor. Journal of Raptor Research 25: 63-67.

STEPHENS, D.W., KREBS, J.R., 1987. Foraging Theory. Monographs in Behavior and Ecology. Princeton University Press; $1^{\text {st }}$ edition, $262 \mathrm{pp}$.

VLACHOS, C.G., PAPAGEORGIOU N.K., 1994. Diet, breeding success, and nest-site selection of the Short-toed Eagle (Circaetus gallicus) in northeastern Greece. Journal of Raptor Research 28: 39-42.

THIOLLAY, J.M., 1968. Essai sur les rapaces du midi de La France. Distribution-Ecologie. Circaète Jean le Blanc, Circaetus gallicus gallicus (Gmelin). Alauda 36: 179-189.

VALVERDE, J.A., 1967. Estructura de una comunidad mediterránea de vertebrados terrestres. Monografías de Ciencias Moderna, 76. Estación Biológica de Doñana 1. Consejo Superior de Investigaciones Científicas, Madrid, 131 pp.

This is an Open Access article distributed under the terms of the Creative Commons Attribution License (https://creativecommons.org/licenses/by/4.0), which permits unrestricted use, distribution, and reproduction in any medium, provided the original work is properly cited. 